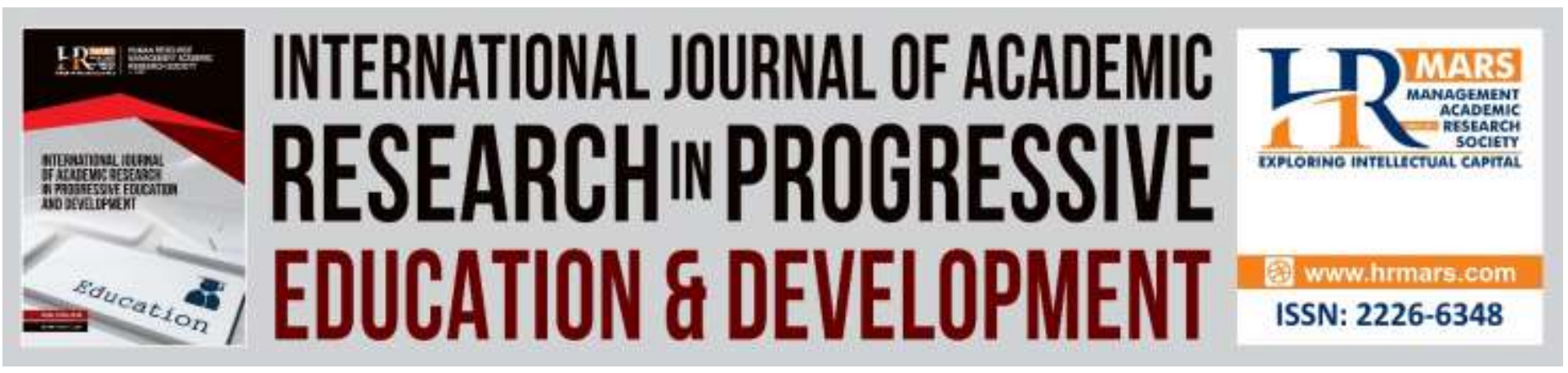

\title{
Enhancement of Higher Order Thinking Skills through Empowerment of Learning Environments
}

Nor Sa'adah Jamaluddin, Suhaida Abdul Kadir, Arnida Abdullah \& Siti Noormi Alias

To Link this Article: http://dx.doi.org/10.6007/IJARPED/v8-i2/5691

DOI: $10.6007 /$ IJARPED/v8-i2/5691

Received: 07 March 2019, Revised: 18 April 2019, Accepted: 30 April 2019

Published Online: 10 May 2019

In-Text Citation: (Jamaluddin, Kadir, Abdullah, \& Alias, 2019)

To Cite this Article: Jamaluddin, N. S., Kadir, S. A., Abdullah, A., \& Alias, S. N. (2019). Enhancement of Higher Order Thinking Skills through Empowerment of Learning Environments. International Journal of Academic Research in Progressive Education and Development, 8(2), 159-167.

Copyright: (C) 2019 The Author(s)

Published by Human Resource Management Academic Research Society (www.hrmars.com)

This article is published under the Creative Commons Attribution (CC BY 4.0) license. Anyone may reproduce, distribute, translate and create derivative works of this article (for both commercial and non-commercial purposes), subject to full attribution to the original publication and authors. The full terms of this license may be seen

at: http://creativecommons.org/licences/by/4.0/legalcode

Vol. 8(2) 2019, Pg. 159 - 167

http://hrmars.com/index.php/pages/detail/IJARPED

JOURNAL HOMEPAGE

Full Terms \& Conditions of access and use can be found at http://hrmars.com/index.php/pages/detail/publication-ethics 


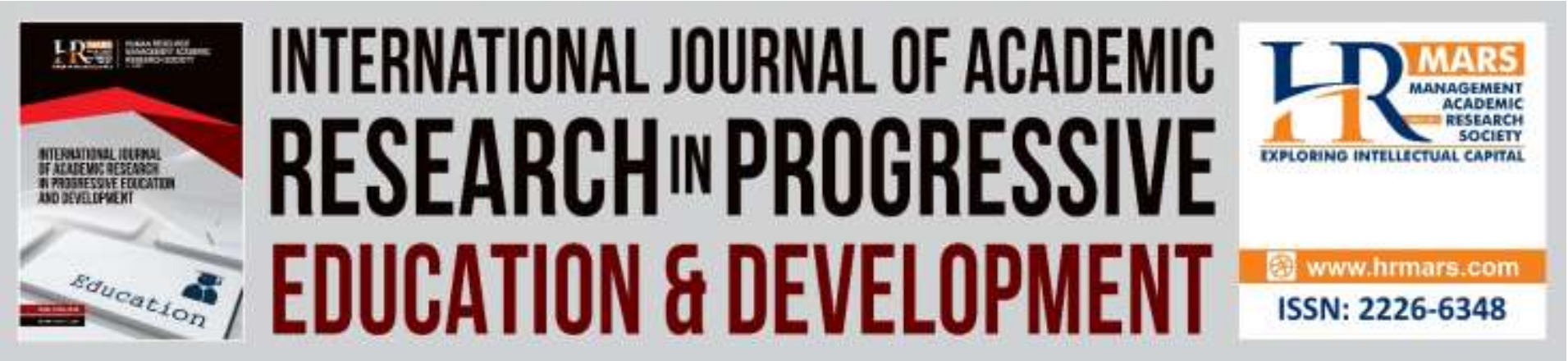

\title{
Enhancement of Higher Order Thinking Skills through Empowerment of Learning Environments
}

\author{
Nor Sa'adah Jamaluddin, Suhaida Abdul Kadir, Arnida Abdullah \& \\ Siti Noormi Alias \\ Faculty of Educational Studies, University Putra Malaysia, Serdang, Selangor
}

\begin{abstract}
Higher Order Thinking Skill (HOTS) is an important skill that is focused in the six aspirations for students through Education Development Plan of Malaysia (EDPM) 2013-2025. Preparing students who are able to master HOTS remain the global education challenge due to the importance of this skill in students in order to prepare them with high marketability value in the future. The transformation of students' low order thinking skill towards high order thinking skill will be able to produce students who are rooted nationally but think internationally which will altogether create Malaysia's education system that is equivalent of international education system. Students' mind transformation can be developed through involvement of learning environment elements which are closely related to the application of HOTS in schools. Thus, this concept paper was written to put forward the issues related to learning environment elements that includes teaching and classroom environment in the application of HOTS among students. The discussions in this article takes into consideration the issues focused by Education Development Plan of Malaysia (EDPM) 2013-2025 that emphasizes HOTS among students in order to create marketability and thus contribute towards the success of nation's education and economic aspects. This research also suggested a few points of improvements related to the discussed issues, as well as provide guideline to ensure HOTS can be successfully cultivated among students.
\end{abstract}

Keywords: Higher Order Thinking Skill, Learning Environment, Classroom Environment.

\section{Introduction}

Educational Development Master Plan (EDMP) 2006-2010 was the curriculum benchmark plan in primary and secondary schools that emphasized the production of first class human capital with the ability to apply Critical and Creative Thinking Skills (CCTS) in daily life (KPM, 2015). In accordance with the global education development, the Education Development Plan of Malaysia (EDPM) 2013-2025 applied the implementation of Standard Curriculum for Primary Schools (SCPS) and Standard Curriculum for Secondary Schools (SCSS) in order to improve the design of previous curriculum which were Integrated Curriculum for Primary Schools (ICPS) and Integrated Curriculum for Secondary Schools (ICSS), (KPM, 2013). The implementation of SCPS and SCSS, which 
INTERNATIONAL JOURNAL OF ACADEMIC RESEARCH IN PROGRESSIVE EDUCATION AND DEVELOPMENT

Vol. 8, No. 2, 2019, E-ISSN: 2226-6348 @ 2019 HRMARS

emphasises High Order Thinking Skill (HOTS) among the students, is the continuation of CCTS that was introduced in the year of 1994 in the National Curriculum through ICPS and ICSS.

Following the development of National Curriculum, Ministry of Education Malaysia (MOE), implemented SCPS since 2011 and SCSS since 2017, with the aim of producing individuals who are able to face the growing global competition in the economic environment driven by innovation. The transformation of SCPS and SCSS are among the government's measurement in strengthening and empowering thinking skills that emphasises interpretation skill among other combination of thinking skills in order to think and evaluate during problem solving (KPM, 2015). Application of HOTS in the school system encourages the students to master the evaluation, application, analyses and creation skills by prioritizing the concepts of understanding and knowing what they learn, not only by mere memorisation (KPM, 2015).

Fraser (1998) explained that the application of HOTS is related to learning environment factors that are seen to have major influence in the successful application of HOTS in Teaching and Facilitating ( $\mathrm{TaF}$ ) in schools. Conducive learning environment has the ability to boost positive development towards application of HOTS as well as inspire mind transformation among students (Che Ahmad, Osman \& Halim, 2013; Fraser, 1998). This is because, good and strong thinking skills are important elements in preparing students with high marketability (Pitan, 2017; Flores, 2012). Marketability values often related to the education aspect because education is one of the platform where the students can display their creativity (Pitan, 2017) and serve as generator of innovation towards completing themselves with skills needed to compete in the job market apart from being an enabler in the economic development as a whole (Razali, 2015). However, the learning environment issues that support application of HOTS remains a question that often debated and focused in this research.

\section{Higher Order Thinking Skills and Learning Environments}

HOTS is defined as a metacognitive process (Yee, Yunos, Othman, Hassan, \& Tee, 2015) that connects the usage mind potential (Tajudin \& Chinnappan, 2016; Onosko \& Newmann, 1994) through learning and observation methods of information processing such as interpretation, analyses and manipulation to solve problems (Yeung, 2015; Lewis and Smith, 1993). The concept of HOTS is also classified as a thinking process that includes formation of concepts, understanding, decision making and problem solving (Mohamed, 2006; Ea, Chang, \& Tan, 2005; Marzano, 1988). The ability of an individual in making connections (Rugutt, 2013) and restructure existing information with new information (Yeung, 2015) for problem solving, analyses of arguments and make predictions would be the exact and proper concept for High Order Thinking Skill (Underbakke, 1993). Thus, HOTS is closely related with the importance of learning to think more effectively (Lo, Cheng, \& Wong, 2017) to ensure that a better method of higher quality is used in information management.

Learning environment was defined (Chen, Fan, \& Jury, 2017; Vinales, 2015; Ramsden 1991; Biggs, 1999; Tessmer \& Harris, 1992) as the quality of teaching in the context of where the teaching happens. Learning environment was characterised as the students' experiences in the context teaching. Those experiences were the students' perspectives on evaluations, objectives, facilities, 
INTERNATIONAL JOURNAL OF ACADEMIC RESEARCH IN PROGRESSIVE EDUCATION AND DEVELOPMENT

Vol. 8, No. 2, 2019, E-ISSN: 2226-6348 @ 2019 HRMARS

teachers and peers involved in the learning environment. In the context of this research, the discussion of the learning environment only focused on the aspect of teachers' teaching and classroom environment that are seen as crucial in influencing the success of HOTS application among students.

\section{Issues on HOT's Application}

It is undeniable that the successful application of HOTS among students during TaF in schools contributed towards the positive development in the nation's educational aspect. However, the issues of teaching and classroom environment (Nordin, 2013) often questioned due to the fact that these two elements of learning environment are the key factors of success (Purkey \& Smith, 1983) of the HOTS application among students through metacognitive experiences (Thomas, Au, \& Mee, 2005). The teachers who teach should emphasise the application of HOTS other than CCTS during TaF process (Ali and Noordin, 2010), however the attitude of teachers who are too focused in the teaching contents during teaching and facilitating process compared to emphasis on the development of critical thinking among students more or less affects the cognitive, affective and psychomotor development of each student (Hassan, 2012). This kind of teachers' behaviour proves that the application of teacher-centred teaching techniques is often given importance (Nordin, 2013; Mladenovic, 2001). This situation threatens the students' development because through teacher-centred teaching techniques, the active involvement of students are rejected during teaching and learning sessions that results in competency performance of students that are stunted, low level and disappointing (Abu \& Eu, 2014).

Kennedy, Fisher and Ennis (1991) clarified that the often existing question in the issue of critical thinking skill involving elements of teaching and learning were the teacher giving too much attention to contents of the subjects (Lo, Cheng, \& Wong, 2017; Mladenovic, 2001) apart from confusion among the teachers on which thinking considered good, and knowledge application techniques that were acquired through creativity and practicality were not emphasised (Yeung, 2015; Mohd \& Hassan, 2005). Past researchers also found uncertainty, lack of knowledge and lack of confidence among teachers regarding the appropriate strategies of HOTS application among students during teaching and learning resulted in teacher-centred teaching techniques and subject content as main focus (Ball \& Garton, 2005; Jimenez \& Diaz, 1997 and Whittington, 1997).

The classroom environment (Hanafi, Hasnah, Mokhtar, Safani, Siti \& Rozniza, 2013) that involves the number of students in a class (Rasid \& Rozita, 2012) contributes towards a good and effective teaching and learning outcome. This is because, when the number of students in a classroom is too large, it pushes the teachers to choose teaching and learning activities that are more teacher-centred, content-centred, and discipline-centred in order to ensure order in classrooms. Thus, the best way according to the teachers in order to ensure fair subject delivery to the large number of students will be through methods such as lecture, usage of overhead projector (OHP) and power-point presentation on the liquid crystal display (LCD) (Rasid \& Rozita, 2012). This situation, to an extent, disrupts the active movement of the students and blocks the students' thinking skills development.

Marohaini (2004), Rahim (2005) and Awang (2006) proved through their researches that 
teachers' teaching attitude and practices in the classrooms were the reason for students' failure in developing their learning potential, apart from obstructing the students' mind transformation. Marohaini (2004) stated concerns because she found that traditional learning approaches uses one-way interaction which was being practiced largely by teachers on classrooms. This finding was supported by Awang (2006) that added while criticising the educational practices in schools that are unable to fulfil the learning principles and develop the students' individual potential.

\section{Improvement on HOTS Application}

The elements of learning environment that contributed toward the failure in HOTS application during teaching and learning sessions should be taken seriously in order to achieve the aim of the government through EDPM (2013-2025) which is to make the nation's education aspect on par with developed nations. Thus, a continuous improvement is needed to enable HOTS application among students so they will be able to succeed and fulfil the aim as a whole. Such improvements that need to be focus on are (1) student-centred teaching; (2) questioning technique; (3) classroom arrangement.

Transformation of teaching and learning process should be parallel with the transformation of National Curriculum. Therefore, transformation towards SCPS and SCSS inspires changes in teaching and learning which is teacher-centred teaching towards student-centred. This is mainly because student-centred learning will be able to stimulate the students to think through implemented activities such as exploration, investigation and learning based on projects where teachers play the role of facilitators (KPM, 2014). The change of teaching and learning concept $(\mathrm{TaL})$ to teaching and facilitating (TaF) which will provide a better support to development of HOTS environment considering that the usage of thinking tools and questioning techniques (Kamboj \& Singh, 2015) are focused.

HOTS is the motivator for students to explore, investigate and practice inquiry learning in order to find solutions to activities that challenge their mind through high order questioning process (Tan \& Halili, 2015). This provides a broader opportunity for students to exhibit their potential (Wismath, Orr, \& MacKay, 2015) and bring out their hidden talent (Kamboj \& Singh, 2015). In planning TaF student-centred, the teachers need to place the students' ability to master HOTS as the main objective so that the planning fulfil the needs of HOTS apart from supporting the government's aim of EDPM (2013-2025) that targets mastery of multiple skills, always up-to-date with the development of educational policies and issues, expert in pedagogy, uses latest technology (Kamboj \& Singh, 2015) and cultivates values with the aim of developing students with good character and personality.

Besides, the usage of questioning techniques in teaching and facilitating is one of the strategies that fulfils the particular aim and needs apart from encouraging the students to think in high order. this is because, creating questions and questioning techniques are one of the often used stimulations to bring out talents, identify level of comprehension, identify interest, sharpen and evaluate the ability of students in particular matter (Othman, Aris, Mohammed, Zaid, \& Abdullah, 2014). Posed questions will be categorised as good questions based on the level, scope and focus aspects (Othman et al., 2014). However, increasing high order questions in TaF activities is one of the methods in application of HOTS that will motivate the students to be more creative 
INTERNATIONAL JOURNAL OF ACADEMIC RESEARCH IN PROGRESSIVE EDUCATION AND

DEVELOPMENT

Vol. 8, No. 2, 2019, E-ISSN: 2226-6348 @ 2019 HRMARS

and critical in thinking.

According to Art Costa and Bena Kallick (Arthur \& Bena, 2000), an effective question should fulfil these criteria: (1) has a particular aim and goal to be achieved; (2) the needs of the question is stated clearly; (3) uses few, clear and concise words; (4) provokes the thinking to stimulate students to respond; (5) involves question that leads to other questions and probes deeper; (6) uses limited scope because a question with many parts can be confusing; (7) and adapted to the ability of the students. Thus, teachers need to be smart in deciding the types of questions that can be asked to the students to ensure the establishment of stimulation for continuous thinking.

Classroom is the place where the activities of teaching and facilitating takes place (Hanafi et al., 2013). The environment and arrangement of the classroom remain as main aspects that need to be emphasised in preparing classrooms that support HOTS application. However, a more important matter that needs focus is the number of students in a class (Rasid, Soaib \& Zakaria, 2009). The number of students in each class should be appropriate with the area of the classroom (Nordin, 2013) by considering the ratio of students and teachers (Rozita, 2012) so that TaF can be carried out in a happy, active and excellent situation.

Classroom environment that supports HOTS application must be cheerful with the exhibition of the students' work in the classroom (Rasid and Rozita, 2012) and encourage active movement of the students during learning. On the other hand, the classroom arrangement must be student-centred where the students will be able to sit in groups which will enable and facilitate interaction and collaboration (Nordin, 2013). Based on the HOTS elements guidebook that was produced by MOE (KPM, 2014), suggested classroom arrangement that supports HOTS application during TaF is as shown in Figure 3. In overall, the wisdom and thoughtfulness of the teachers in playing their role optimally in producing a classroom that is harmony, conducive and dynamic can provide a high motivation (Staker \& Horn, 2012) among the students which will push them to continuously excel in education and become excellent human capital.

\section{Conclusion}

The teachers' creative and innovative teachings, added with conducive classroom environment are the main aspects that will contribute toward the successful application of HOTS during TaF in schools which in turn makes TaF more effective and meaningful. Therefore, teachers need to clearly understand that the development of mind, emotion, attitude and values of the students are closely related to the practice of teaching and learning at school. The application of creative and innovative teaching and learning has the ability to encourage students' positive development from the aspects of cognitive, affective and psychomotor. The ability of the teachers in mastering the learning environments which includes the aspects of teaching and classroom environment will contribute towards the successful achievement of education aim as stated in EDPM 2013-2025.

\section{Suggestion for Further Research}

From this concept paper, I suggest for further research to continue with focusing on the learning environment for a particular subject in assessing the development of HOT pupils in a focused 
INTERNATIONAL JOURNAL OF ACADEMIC RESEARCH IN PROGRESSIVE EDUCATION AND

DEVELOPMENT

Vol. 8, No. 2, 2019, E-ISSN: 2226-6348 @ 2019 HRMARS

subject. The findings of this further study will illustrate the suitability of the learning environment for enhancing HOT on particular subject and other subjects in general.

\section{Acknowledgement}

The researchers also like to acknowledge the Ministry of Higher Education (MOHE) and University Putra Malaysia for the financial funding of this research through "Geran - Putra IPS" UPM (GPIPS/2018/9608800), for Research University Grant (RUG).

\section{Corresponding Author}

Nor Sa'adah binti Jamaluddin

Faculty of Educational Studies, Universiti Putra Malaysia.

Email: saadahjamaluddin86@gmail.com

\section{References}

Abu, N. E., \& Dan Eu L. K. (2014). Hubungan antara Sikap, Minat, Pengajaran Guru dan Pengaruh Rakan Sebaya terhadap Pencapaian Matematik Tambahan Tingkatan 4. Jurnal Kurikulum dan Pengajaran Asia Pasifik, Bil 2, Isu 1.

Anderson, O. W., \& Krathwohl, D. R. (2001). Taxonomy for Learning, Teaching, and Assessing: A Revision of Bloom's Taxonomy of Educational Objectives. A Bridged Edition. New York: Addison Wesley Longman, Inc.

Lewis, A. \& Smith, D. (1993). Defining Higher Order Thinking. Theory Into Practice, 32:3, 131-137, DOI: $10.1080 / 00405849309543588$.

Ahmad, C. N., Osman, K. \& Halim, L. (2013). Persekitaran Pembelajaran Aspek Fizikal dan Psikososial. Bangi: Universiti Kebangsaan Malaysia.

Chen, C., Fan, J., \& Jury, M. (2017). Are Perceived Learning Environments Related to Subjective WullBeing? A Visit to University Students. Learning and Individual Differences, 54. Page 226-233.

Ea, J., Chang, A. \& Tan, O. S. (2005). Thinking About Thinking: What Educators Need to Know. Singapore: National Institute of Education, Nanyang Technological University, McGraw Hill Education.

Fraser, B. J. (1998). Classroom Environment Instruments: Development, Validity and Applications. Learning Environments Research, 1, 7-33.

Lo, J. T., Wong, I. N. C. D. E. M. (2017). "Hong Kong's Curriculum Reform: Intentions, Perceptions and Practices". Asian Education and Development Studies, Vol. 6 Issue: 1, 95-106. https://doi.org/10.1108/AEDS-03-2016-0023 Permanent.

Biggs, J. (1999) What the Student Does: Teaching for Enhanced Learning. Higher Education Research \& Development, 18:1, 57-75.

Kamboj, P., \& Singh, S. K. (2015). Effectiveness of selected Teaching Strategies in Relation to the Learning Styles of Secondary School Students in India. Interchange 46 (3). Page 289-312.

KPM (2013). Pelan Pembangunan Pendidikan Malaysia 2013-2025 (Pendidikan Prasekolah hingga Lepas Menengah). Putrajaya: KPM.

KPM (2015). Kemahiran Berfikir Aras Tinggi (KBAT) dan Perlaksanaan KBAT di Sekolah. Buletin Anjakan, 1-4. Retrieved from http://www.padu.edu.my/files/Anjakan_Mac_2015.pdf 
Lina, D. K. (2013). Assessment and Instruction to Promote Higher Order Thinking tn Nursing Students. Nurse Education Today, 34, 789-794.

Lo, J. T., Cheng, I. N., \& Wong, E. M. (2017). Hong Kong's curriculum reform: intentions, perceptions and practices. Asian Education and Development Studies, 6(1), 95-106.

Marzano, R. J. (1988). Dimensions of thinking: A framework for curriculum and instruc- tion. Alexandria, VA: Association for Supervision and Curriculum Development.

Underbakke, M., Peterson, J. M. B. D. D. (1993). Researching and Developing the Knowledge Base for Teaching Higher Order Thinking. Theory into Practice, Vol. 32, No. 3, 138-146.

Mohamed, S. Z. (2006). Kesan Pendekatan Penyebatian Kemahiran Berfikir Kreatif dalam Pengajaran Karangan Deskriptif dan Karangan Imaginatif dalam Kalangan Pelajar Tingkatan IV. Tesis Doktor Falsafah: Universiti Sains Malaysia.

Onosko, J. J., \& Newmann, F. M. (1994). Creating more thoughtful learning environments, In J.N.Mangieri \& C.C. Block (Eds.). Creating powerful thinking in teachers and students: Diverse perspectives. Fort Worth: Harcourt Brace College Publishers.

Othman, S. Z., Aris, B., Mohammed, H., Zaid, N. M., \& Abdullah, Z. (2014). Penerapan Kemahiran Berfikir Aras Tinggi Melalui Model Stesen Rotasi Pelbagai Mod. Konvensyen Antarabangsa Jiwa Pendidik 2014, (August), 11-13.

Pitan, O. S. (2017). Graduate employees' generic skills and training needs. Higher Education, Skills and Work-Based Learning, 7(3), 290-303.

Purkey, S., \& Smith, M. (1983). Effective school: A review. The Elementary School Journal, 83(4), 427-452.

Ramsden, P. (1991). A Performance Indicator of Teaching Quality in Higher Education: The Course Experience.

Rugutt, J. K. (2013). Linking Teaching And Learning Environment Variables To Higher Order Thinking Skills : A Structural Equation Modeling Approach. Application of Structural Equation Modeling in Educational Research and Practice Contemporary Approaches to Research in Learning Innovations, (1997), 217-239.

Russell, M. R. (2011). Reflections on Learning: Students' Insights on Their Learning in A Legal Research Skills Course in The Core Curriculum. The Law Teach, 45 (1), 45-62.

Tajudin, N. M., \& Chinnappan, M. (2016). The Link between Higher Order Thinking Skills, Representation and Concepts in Enhancing TIMSS Tasks. International Journal of Instruction, 9(2), 199-214.

Tessmer, M., Harris, D. (1992). Analyzing the Instructional Setting: Environmental Analysis. London/Bristol, PA: Kogan Page/Taylor and Francis.

Thomas, G. P., Au, D., \& Mee, K. I. N. (2005). Changing the learning environment to enhance students' metacognition in hong kong primary school classrooms, 221-243.

Vinales, J. J. (2015). learning styles : a guide for mentors, 24(8), 454-457.

Wang, V. \& Farmer, L., (2008). Adult Teaching Methods in China and Bloom's Taxonomy. Int. J. Scholarsh.Teach. Learn, 2 (2), 1-15.

Wismath, S., Orr, D., \& MacKay, B. (2015). Threshold Concepts in the Development of Problemsolving Skills. Teaching and Learning Inquiry: The ISSOTL Journal, 3(1), 63-73.

Heong, Y. M., Md Yunos, J., Othman, W., Hassan, R., Kiong, T. T., \& Mohamad, M. M. (2015). Disparity of Learning Styles and Higher Order Thinking Skills among Technical Students. Procedia - Social 
INTERNATIONAL JOURNAL OF ACADEMIC RESEARCH IN PROGRESSIVE EDUCATION AND DEVELOPMENT

Vol. 8, No. 2, 2019, E-ISSN: 2226-6348@ 2019 HRMARS

and Behavioral Sciences, 204, $143-152$.

Yeung, S. S. (2015). Conception of Teaching Higher Order Thinking: Perspectives of Chinese Teachers in Hong Kong. Curriculum Journal, 26(4), 553-578. 